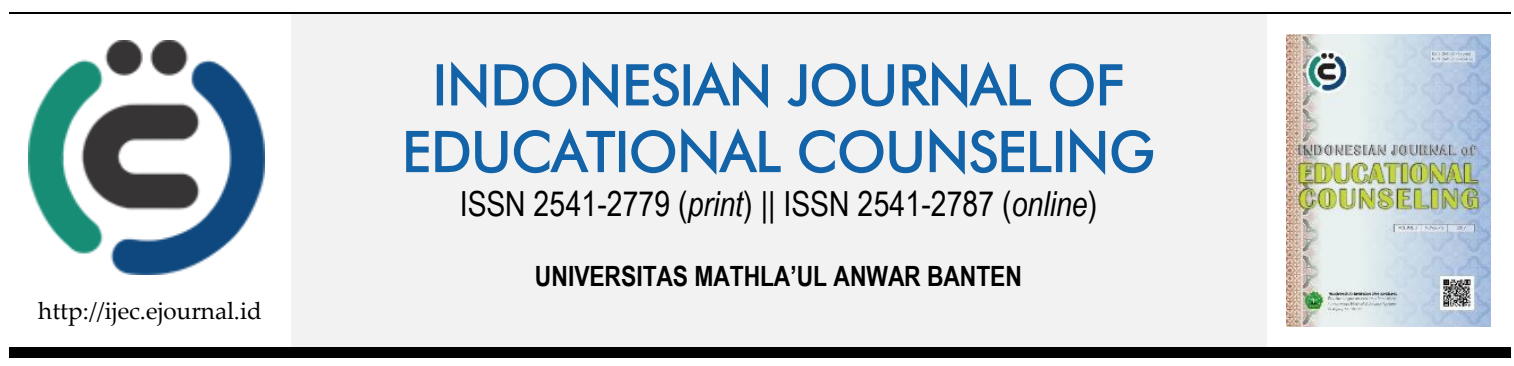

Theoretıcal/Conceptual Artıcle

\title{
Dimensi-dimensi Komunikasi Efektif dalam Relasi Bimbingan dan Konseling
}

\author{
Suherman ${ }^{1}$ \\ 1 Universitas Pendidikan Indonesia
}

\begin{tabular}{ll}
\hline Article History & ABSTRACT \\
\hline $\begin{array}{l}\text { Received: 25.03.2019 } \\
\text { Received in revised form: }\end{array}$ & DIMENSIONS OF EFFECTIVE COMMUNICATION IN GUIDANCE AND \\
01.04.2019 & COUNSELING RELATIONS. The growth of effective communication between \\
Accepted: 10.04.2019 & guidance and counseling teachers and students is a facility to achieve the goal \\
Available online: 05.08.2019 & of guidance and counseling in schools. Quality of communication will \\
& psychologically stimulate students to involve themselves intensively in the \\
process of providing treatment. This condition will encourage students to open & themselves to understand the personal characteristics, and willing to work \\
& together to explore various alternatives for self-development, making choices \\
& and decisions, and solving their problems. Students who are less open to \\
& guidance and counseling teachers are motivated by various factors, including \\
& allegedly by low professional competence of guidance and counseling teachers \\
& in developing communication that facilitates the provision of assistance for \\
students. Thus, guidance and counseling teachers need to have communication \\
competence in order to improve the effectiveness of aid in guidance and \\
counseling services. The dimensions of the communication shall include: (a) the \\
empathic behavior; (b) the acceptance and respect of students; (c) the warmth \\
and attention; (d) openness and sincerity; and (e) concreteness and specificity \\
of expression. \\
KEYWORDS: Problem Solving, Professional Competence, Quality of \\
Communication, Self-Development.
\end{tabular}

DOI: $10.30653 / 001.201933 .112$

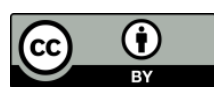

This is an open access article distributed under the terms of the Creative Commons Attribution 4.0 International License, which permits unrestricted use, distribution, and reproduction in any medium, provided the original work is properly cited. (c) 2019 Suherman.

\section{PENDAHULUAN}

Salah satu tujuan bimbingan dan konseling (BK) di sekolah adalah membantu siswa untuk mengembangkan diri, memiliki kemandirian, dan tanggung jawab dalam mengambil pilihan dan keputusan, sehingga siswadapat menghadapi masa depan secara terarah. Siswa diharapkan memiliki kepribadian yang efektif, kreatif, dan produktif, serta mampu berinteraksi, menyesuaikan diri, dan mengembangkan lingkungan kehidupan sebagai fasilitas perkembangan yang kondusif.

${ }^{1}$ Corresponding author's address: Departemen Psikologi Pendidikan dan Bimbingan Universitas Pendidikan Indonesia; Jl. Dr. Setiabudi No.229, Isola, Kec. Sukasari, Kota Bandung, Jawa Barat 40154; Email: suhermanbk@upi.edu 
Layanan bimbingan dan konseling berupaya membantu siswa agar mereka dapat menjalani proses perkembangan secara efektif dan mandiri. Siswa diharapkan memiliki ketangguhan dan kemampuan dalam menghadapi berbagai peluang, mengatasi kendala kehidupan, dan responsif dalam menghadapi kesempatan yang muncul untuk mengaktualisasikan potensi-potensi yang mereka miliki. Dalam era kesejagatan ini, individu dituntut untuk selalu memperbaiki kemampuan dan kecakapannya dalam memilih informasi sehingga dapat mengambil pilihan dan keputusan secara tepat.

Guru BK, sebagai pelaksana layanan bimbingan dan konseling di sekolah, perlu memperhatikan adanya kompleksitas kehidupan masyarakat serta berbagai persoalan yang mungkin ditimbulkannya, yang akan berimbas pada kehidupan remaja. Guru BK seyogianya tertantang untuk menyelenggarakan layanan bimbingan dan konseling yang berorientasi untuk memenuhi tuntutan dan kebutuhan perkembangan siswa sesuai dengan nilai-nilai yang hidup di masyarakat tempat para siswa menjalani perkembangannya. Bimbingan dan konseling perlu menyelenggarakan layanan yang berkualitas, baik dilihat dari segi substansi materi, maupun dilihat dari strategi pelaksanaan layanannya.

Tuntutan mengenai kualitas layanan bimbingan dan konseling yang profesional di atas, mengimplikasikan perlunya guru BK menguasai sejurnlah kompetensi dalam memberikan layanan, baik berupa pengetahuan, keterampilan, maupun etika profesional. Selain itu, mereka juga seyogianya memiliki sejumlah kualitas pribadi yang dapat mendukung perannya sebagai guru bimbingan dan konseling di sekolah.Kompetensi pengetahuan, keterampilan, pribadi, maupun etika profesional, akan menentukan kinerja seorang guru BK yang akan tampak pada saat memberikan bantuan melalui proses komunikasi dengan siswa.

Keberhasilan layanan bimbingan dan konseling di sekolah diawali dengan adanya kesediaan dan keterbukaan siswa untuk secara aktif terlibat dalam proses bimbingan dan konseling. Keterbukaan merupakan dimensi yang sangat mendasar bagi keberhasilan layanan bimbingan dan konseling. Kondisi seperti itu akan terjadi apabila guru bimbingan dan konseling mampu mengembangkan hubungan interpersonal yang kondusif sesuai dengan harapan siswa.

Terciptanya komunikasi guru bimbingan dan konseling dengan siswa yang berkualitas dan sesuai dengan harapan siswa merupakan landasan, dan akan memberikan pengaruh positif bagi terselenggaranya layanan bimbingan dan konseling di sekolah. Disamping dapat mengundang siswa untuk melibatkan diri secara aktif dalam proses bimbingan, kondisi hubungan yang fasilitatif dapat memotivasi siswa untuk melakukan berbagai upaya yang diperlukan guna mencapai tujuan yang ingin diraihnya. Proses bimbingan dan konseling akan terfasilitasi apabila siswa lebih terbuka dalam membahas persoalan-persoalan yang dihadapi, sehingga tumbuh kerjasama dalam merumuskan pemecahan masalah dan pengembangan dirinya.

Kurang berkembangnyakomunikasi siswa dengan guru bimbingan dan konseling dapat disebabkan oleh sejumlah faktor.Namun, semua itu pada akhirnya akan bermuara pada kemampuan profesional guru bimbingan dan konseling dalam mengembangkan kondisi yang komunikatif dalam layanan bimbingan dan konseling.

Untuk keberhasilan layanannya, guru bimbingan dan konseling harus berupaya secara sungguh-sungguh mengembangkan komunikasi yang efektif dengan siswa. Tanpa 
itu, layanan bimbingan dan konseling akan mengalami kegagalan. Dengan tumbuhnya komunikasi yang memfasilitasi siswa, akan berkembang kepercayaan siswa terhadap bantuan yang diberikan oleh guru bimbingan dan konseling di sekolah.

Berdasarkan latar belakang di atas, maka tujuan kajian ini, yaitu: 1) mengidentifikasi dimensi-dimensi komunikasi efektif dalam bimbingan dan konseling agar guru BK dapat memberikan bantuan secara efektif dalam layanan bimbingan dan konseling di sekolah; 2) Mengeksplorasi strategi pengembangan kecakapan komunikasi bagi Guru BK dalam layanan bimbingan dan konseling di sekolah.

\section{KAJIAN LITERATUR}

Guru bimbingan dan konseling perlu memiliki kualitas profesional dengan didukung oleh lima kompetensi, yaitu: 1) dorongan untuk menampilkan perilaku yang mendekati standarideal, 2) meningkatkan dan memelihara citra profesi, 3) keinginan untuk senantiasa mengejar kesempatan pengembangan profesional yang dapat meningkatkan dan memperbaiki kualitas pengetahuan dan keterampilan, 4) mengejar kualitas dan cita-cita profesi, dan 5) memiliki kebanggaan terhadap profesinya.

Terdapat tiga kelompok kompetensi yang seyogianya dikembangkan dalam pendidikan calon guru bimbingan dan konseling meliputi hal-hal berikut. 1) Kemampuan profesional yang harus dimiliki guru bimbingan dan konseling sebagai seorang pribadi; 2) Kemampuan profesional yang harus dimiliki guru bimbingan dan konseling dalam menciptakan situasi yang menimbulkan pengaruh; 3) Kemampuan profesional yang harus dimiliki guru bimbingan dan konseling agar siswa mau meminta dan menerima bantuan guru BK (Shertzer \& Stone, 1981, p. 42).

Bimbingan dan konseling merupakan layanan yang sangat mendasar dalam proses pendidikan.Peranan penting bimbingan dan konseling dalam membantu siswa antara lain dalam menetapkan pilihan dan mengambil keputusan, mengatasi permasalahan, dan memfasilitasi siswa dalam mengembangkan potensi-potensi yang mereka miliki.

Layanan bimbingan dan konseling berupaya membantu siswa dapat memanfaatkan kesempatan dan peluang yang tersedia secara maksimal, dan meminimalkan berbagai hambatan yang mungkin terjadi dalam menjalani proses perkembangannya. Indikator keberhasilan layanan bimbingan dan konseling adalah tercapainya perwujudan diri. Siswa dapat menjalani kehidupan secara efektif dan produktif serta terhindar dari kehampaan.

Bimbingan dan konseling berlangsung dalam proses interaksi antara guru bimbingan dan konseling dengan siswa, yang bertujuan membantu siswa untuk: (1) memahami, menerima, mengarahkan, dan mengembangkan minat, bakat, dan kemampuan secara optimal, (2) menyesuaikan diri dengan keadaan lingkungan keluarga, sekolah, dan masyarakat, dan (3) merencanakan kehidupan masa depan yang sesuai dengan tuntutan dunia pada saat ini maupun di masa yang akan datang.

Komunikasi bimbingan dan konseling dalam penelitian ini merujuk pada konsep "helping-relationship" yang dikemukakan oleh Brammer (2003, p. 40). Konsep ini dapat dimaknai sebagai komunikasi pemberian bantuan dalam layanan bimbingan dan konseling. Dalarn komunikasi pemberian bantuan terdapat dua subyek yang terlibat, 
yaitu: guru bimbingan dan konseling/konselor (orang yang memberi bantuan), dan siswa/konseli (orang yang menerima bantuan).

Berdasarkan pengertian tersebut, bantuan yang diberikan oleh guru bimbingan dan konseling diarahkan agar siswa tumbuh dan berkembang, yaitu munculnya kesadaran bahwa banyakstrategi yang dapat dipilih dalam proses pengembangan diri, merasa tentram dalam membuat keputusan, mampu memecahkan masalah, dan mampu mengekspresikan perasaan dan kemampuan yang dimilikinya. Kondisi ini akan terjadi apabila kepribadian guru bimbingan dan konseling, karakteristik, sikap serta orientasi nilai, dan keterampilan memahami siswa, memberikan alternatif pemecahan masalah, dan mampu memfasilitasi siswa untuk tumbuh dan berkembang. Dengan komunikasi bimbingan dan konseling yang efektif, siswa diharapkan dapat menjalani kehidupan yang lebih bermakna.

Komunikasi bimbingan dan konseling cukup sulit untuk didefinisikan karena hubungan dimaksud ditentukan oleh orientasi nilai yang dianut oleh masing-masing pihak, guru bimbingan dan konseling dan siswa, juga oleh situasi yang muncul pada saat pemberian bantuan berlangsung.

Bimbingan dan konseling sebagai proses komunikasi, menunjukkan bahwa suatu hubungan dapat dikatakan membantu apabila: (a) dapat memfasilitasi konseli (siswa) untuk tumbuh dan berkembang, terutama munculnya kesadaran diri betapa banyak alternatif yang dapat ia pilih untuk menuju hidup dengan bahagia dan memiliki kesiapan untuk berperilaku sesuai dengan alternatif pilihan terbaiknya, (b) bantuan itu terjadi karena adanya persetujuan (agreement) sebagai kontrak psikologis guru bimbingan dan konseling dengan siswa, (c) bantuan itu dapat memenuhi harapan dan kebutuhan siswa.

Bantuan yang diberikan kepada siswa bertujuan agar dapat mengaktualisasikan diri dengan penuh kebahagiaan dan bermakna baik bagi dirinya maupun bagi lingkungannya. Helping people can be counstrued as a process of assisting konselis toward higher levels of self-actualization and the joyful realization of their unused possibilities. Secara skematik, proses bantuan dapat dianalisis dari empat dimensi, (1) personality of helper, (2) helping skills, (3) growth-facilitating condition, dan (4) specific outcome Brammer (2003, p. 40). Lebih lanjut proses membantu tersebut dapat dipetakan dalam Tabel 1.

Tabel 1. Proses Bantuan

\begin{tabular}{llll}
\hline $\begin{array}{l}\text { Personality of } \\
\text { Helper }\end{array}$ & Helping Skills & $\begin{array}{l}\text { Growth-Facilitating } \\
\text { Condition }\end{array}$ & Specific Outcomes \\
\hline Traits & For Understanding & Trust & For the person \\
\hline Attitudes & For comfort & Respect & For society \\
\hline Values & For Action & Freedom & For the Helper \\
\hline
\end{tabular}

(Dikutip dari Brammer (2003, p. 40).

Keberhasilan proses bantuan sangat dipengaruhi oleh kepribadian guru bimbingan dan konseling dan keterampilannya dalam memberikan bantuan. Kedua faktor tersebut akan menjadi fasilitator bagitumbuhnya kesadaran siswa, ia menyadari begitu banyak alternatif pengembangan diri dan pemecahan masalah yang dapat dipilih. Kesadaran inilah yang mendasari proses pengambilan keputusan secara tepat melalui komunikasi bimbingan dan konseling. Lebih jauh lagi keputusan tersebut akan menimbulkan dampak yang spesifik sebagai hasil dari komunikasi bimbingan dan konseling, baik bagi 
perkembangan pribadi individu, masyarakat, dan guru bimbingan dan konseling itu sendiri.

Terdapat tiga dimensi kepribadian guru bimbingan dan konseling yang terkait dalam proses komunikasi bimbingan dan konseling. Traits yaitu ciri-ciri pribadi guru bimbingan dan konseling yang meliputi kemampuan, bakat, dan minat untuk memberikan bantuan terliadap orang lain. Attitudes yaitu sikap dan perilaku guru bimbingan dan konseling baik ketika memberikan bantuan maupun pada lingkup hidup lainnya. Values yaitu onentasi nilai guru bimbingan dan konseling yang akan mewarnai kriteria penilaian suatu bantuan yang diberikannya. Orientasi nilai siswa harus dijadikan rujukan yang kongruen dengan orientasi nilai guru bimbingan dan konseling.(Brammer , 2003, p. 5).

Ada tiga keterampilan guru bimbingan dan konseling dalam mengembangkan komunikasi bimbingan dan konseling. Pertama., keterampilan memahami dan memberikan pemahaman tentang diri dan permasalahan siswa. Guru BK perlu memahami siswa dengan segala karakteristik dan permasalahannya.Disamping itu, siswa perlu mendapat bantuan guru bimbingan dan konseling untuk memperoleh kesadaran bahwa ia memiliki potensi untuk berkembang, dan pemahaman bahwa ia memiliki masalah. Kedua, kemampuan untuk membantu siswa membuat beberapa alternatif sebagai solusi dari masalah yang dihadapi dan pengemhangan potensi dirinya.Keterampilan ini mengarahkan siswa agar mampu mengambil keputusan secara tepat. Ketiga, keterampilan membantu siswa agar siap melakukan dan sanggup menerima segala konsekuensi dari keputusan yang diambilnya.

Terdapat tiga kondisi yang memfasilitasi siswa bagi tumbuhnya kesadaran diri, merasa tenteram dalam membuat keputusan, mampu memecahkan masalah, dan merasa bebas dalam mengekspresikan perasaan.Ketiga kondisi tersebut adalah trust (kepercayaan), respect (penghargaan dan penghormatan), freedom (kebebasan).

\section{DISKUSI}

Keberhasilan layanan bimbingan dan konseling dapat dicapai apabila guru BK mampu mengembangkan komunikasi efektif dengan siswa.Perilaku-perilaku guru bimbingan dan konseling tersebut merupakan prasyarat untuk mencapai tujuan bimbingan dan konseling yang dikembangkannya.Kompetensi komunikasi dimaksud meliputi: (1) perilaku empatik, (2) penerimaan dan penghargaan terhadap siswa, (3) kehangatan dan perhatian, (4) keterbukaan dan ketulusan, dan (5) kekonkretan dan kekhususan ekspresi.

\section{Empati}

Empati merupakan kemampuan untuk memahami siswa dan mencoba menggugah siswa bahwa ia dipahami oleh guru BK. Dalam perlakuan empati, guru BK berupaya untuk menempatkan diri pada dunia siswa dengan menggunakan rangka rujukan siswa (client frame of reference). Proses penempatan diri seperti itu, oleh disebut sebagai gerakan eksternal ke internal (external to internal movement). (Brammer, 2003, p. 42).

Tolok ukur keberhasilan empati guru BK adalah kemampuan siswa untuk menggunakan pemahaman empati guru BK untuk memahami dirinya. Pemahaman 
empati tidak cukup dialami dan dirasakan oleh guru BK saja, melainkan pemahaman tersebut harus pula dirasakan dan dialami sendiri oleh siswa. Empati adalah ...to be helped a client must be understood. Further this undestanding must be communicated. A client must known what you are listening carefuly and that your understand is this does to put your self in another's shoes (Brammer, 2003).

Terdapat lima perilaku empati guru bimbingan dan konseling. Pertama, guru bimbingan dan konseling meninjau permasalahan dari sudut pandang siswa, dan berusaha menempatkan diri pada posisi dan kerangka berpikir siswa. Dengan memposisikan diri seperti ini, guru bimbingan dan konseling akan mampu mengungkapkan masalah siswa sebagaimana yang siswa rasakan. Kedua, guru bimbingan dan konseling merasa bersama dengan siswa, sehingga ia peduli terhadap perkembangan diri siswa dan mau memperhatikan secara keseluruhan ungkapan-ungkapan siswa. Ketiga, setelah melalui dua prilaku empati di atas, guru bimbingan dan konseling mulai membantu siswa untuk memahami masalah yang dialaminya. Guru bimbingan dan konseling berupaya menuntun siswa untuk memahami diri serta permasalahannya. Keempat, meski guru bimbingan dan konseling sudah berada dalam posisi dan kerangka berpikir siswa, ia tetap konsisten dengan jati dirinya. Guru bimbingan dan konseling tidak kehilangan jati diri dalam posisinya untuk memberikan bantuan. Kelima, melalui keempat prilaku empati di atas, guru bimbingan dan konseling seyogianya mampu menafsirkan ungkapan siswa secara tepat. Bahkan ia mampu mengarahkan siswa untuk menyimpulkan permasalahan yang dihadapinya melalui dorongan dari ungkapan guru bimbingan dan konseling.Para ahli cenderung setuju bahwa empati merupakan hal yang amat penting dan esensial dalam proses konseling. Begitu pentingnya perilaku empati dalam komunikasi bimbingan dan konseling, sehingga empati merupakan jantung dari proses komunikasi bimbingan dan konseling yang efektif.

\section{Penerimaan dan Penghargaan}

Penerimaan dan penghargaan terhadap siswa sebagaimana adanya akan menempatkan siswa sebagai individu fungsional. Ini merupakan perwujudan dari pengakuan individualitas dan penghargaan diri siswa sebagai manusia. Menurut Rogers, kondisi ini disebut sebagai unconditional positive regard ditafsirkan sebagai "... the complete acceptence of all the client's characteristics and behaviors... (Osipow, Walsh, \& Tosi, 1984, p. 19). Egan (2002) menyebut, unconditional postive regard and resfect, yang dapat dimaknai sebagai non judgmental and non-reservation attitude, yaitu sikap yang tidak memberikan penilaian dan penerimaan tanpa syarat terhadap siswa. Carkhuff (2000) menyebutnya dengan communicate unconditonal regard yang berarti jalinan komunikasi tanpa syarat yaitu penerimaan terhadap siswa sebagaimana adanya.

Uraian di atas menunjukkan bahwa yang dimaksud dengan penerimaan dan penghargaan dalam mengembangkan komunikasi bimbingan dan konseling adalahjalinan komunikasi yang menerima siswa apa adanya yang mengimplikasikan bahwa siswa dipandang sebagai pribadi yang bermakna dan berguna secara tulus. Konsep ini menuntut tindakan guru bimbingan dan konseling bukanlah sebagai pengendali tetapi terarah sebagai fasilitator perkembangan siswa.

Diyakini bahwa dengan penerimaan dan penghargaan yang tulus, maka siswa akan mampu mengekspresikan perasaan dan permasalahannya. Penerimaan dan penghargaan dapat diekspresikan dengan ungkapan yang tulus, penerimaan, dan empati. 


\section{Kehangatan dan Perhatian}

Kehangatan dan perhatian adalah suatu kondisi penuh persahabatan yang ditunjukkan dengan ekspresi non-verbal seperti senyuman, kontak mata, dan perilaku non-verbal lainnya.Kondisi ini sebagai warmth and caring.Brammer (2003:38) menegaskan bahwa "warmth is condition of friendliness and considerateness manifested by smilling, eye contact, and nonverbal attending behavior".

Guru bimbingan dankonseling dituntut untuk menunjukkan keterlibatan emosi dengan suasana hubungan yang hangat dan penuh perhatian. Dengan adanya kehangatan dan perhatian yang tulus, siswa akan merasa aman, nyaman dan tenteram untuk mengadakan komunikasi dengan guru bimbingan dan konseling. Karena begitu pentingnya kehangatan dan perhatian dalam komunikasi bimbingan dan konseling, kaum Freudian memandang bahwa kehangatan dan perhatian merupakan kekuatan yang sangat berarti dalam proses komunikasi bimbingan dan konseling. (Nugent, 2001).

Untuk menciptakan kondisi warmth (kehangatan), sikap duduk mengarah kepada siswa dan responsif kepadanya merupakan hal yang esensial. Dalam kontak mata, guru bimbingan dan konseling hendaknya memandang siswa secara spontan tetapi menunjukkan adanya perhatian dan keinginan untuk mendengarkan dan merespon pernyataan-pernyataan siswa. Ekspresi wajah guru bimbingan dan konseling tidak kaku, tidak dingin, dan sama sekali tidak ada kesan menyeramkan.

Berdasarkan uraian di atas, dapat disimpulkan bahwa indikator komunikasi yang hangat dan penuh perhatian guru BK pada saat mengembangkan komunikasi bimbingan dan konseling adalah: (1) memperlakukan siswa secara bersahabat, (2) menunjukkan kepedulian terhadap perkembangan dan masalah siswa, (3) membantu melancarkan ungkapan-ungkapan siswa, (4) memelihara perhatian penuh kepada siswa, dan (5) mengungkapkan kembali pernyataan siswa secara tepat.

\section{Keterbukaan dan Ketulusan}

Keterbukaan mengandung arti bahwa guru bimbingan dan konseling mengembangkan sikap yang menunjukkan kondisi apa adanya. Dalam pengertian lain, keterbukaan adalah perilaku yang menunjukkan keaslian, sesuai dengan keadaan yang sebenarnya,tidak melebih-lebihkan, tidak menutup-nutupi keberadaan dirinya, serta memiliki sikap terbuka untuk dipuji, dikritik, dan terbuka atas berbagai masukan dari orang lain.

Bergin dan Galfield (1999) mengartikan keterbukaan sebagai suatu pernyataan dimanakata-kata guru bimbingan dan konseling konsisten dengan perilakunya. Sedangkan Tyler mengartikan keterbukaan adalah kemauan untuk mencoba mengetahui dan memahami masalah siswa, Menurut Combs, keterbukaan guru bimbingan dan konseling terhadap siswa dalam komunikasi bimbingan dan konseling dilandasi oleh adanya sikap saling mempercayai.

Untuk menunjukkan kondisi yang terbuka, pada saat melakukan komunikasi bimbingan dan konseling, Egan (1982, p. 132) memberikan rambu-rambu sebagai berikut: (1) guru bimbingan dan konseling jangan terlalu bersikap formal-profesional, (2) berbuatlah spontan, tetapi tidak sembarangan, (3) jangan menunjukan sikap mempertahankan diri, (4) berusaha untuk tetap konsisten, (5) guru bimbingan dan konseling bersikap bijaksana,dan (6) berbagi pengalaman dengan siswa. Carkhuff (2000) 
membagi dua tahapan perilaku keterbukaan dan ketulusan, yaitu: tahapan responsive set (tahap mendengarkan dan memperhatikan siswa), tahapan initiative set (tahap pengambilan inisiatif dengan proses modeling).

Keterbukaan dan ketulusan sedikit berbeda dengan aspek-aspek komunikasi bimbingan dan konseling lainnya. Keterbukaan lebih bersifat non-verbal, sedangkan aspek lainnya lebih bersifat verbal. Konsekuensinya keempat aspek lebih mengarah kepada skill verbal sedangkan ketulusan dan keterbukaan akan sangat tergantung kepada kejujuran, apakah seorang guru bimbingan dan konseling betul-betul tulus dan terbuka dalam memberikan layanannya.

Mengacu kepada uraian di atas, keterbukaan dan ketulusan dapat dilihatdengan menganalisis lima indikator kemampuan guru bimbingan dan konseling dalam hal: (1) memberikan kebebasan kepada siswa untuk berekspresi dalam mengemukakan pikirandan perasaannya, (2) menumbuhkan kepercayaan kepada siswa bahwa guru bimbingan dan konseling dapat membantunya dalam proses pengembangan diri dan pemecahan masalah, (3) menampilkan perilaku yang tidak dibuat-buat, (4) menanggapi sifat-sifat yang positif dan negatif siswa secara bijaksana dan konstruktif, dan (5) berupaya untuk konsisten antara perbuatan dengan ucapannya.

\section{Kekonkretan dan Kekhususan Ekspresi}

Kekonkretan dan kekhususan ekspresi merupakan aspek yang penting dalam komunikasi bimbingan dan konseling. Ditegaskan ole Ivey dan Authier bahwa, ...specifity of expression is important in effective helping session (Brammer, 2003, p. 42).

Kekonkretan dan kekhususan ekspresi merupakan keakuratan dan kejelasan kumunikasi Dengan tilikan yang berbeda, Carkhuff (2000) menjelaskan lima pengertian tentang kekonkretan sesuai dengan tahapan proses bantuan yang dilakukannya. Pertama, pada tahap attending (prehelping), kekonkretan dan kekhususan diartikan sebagai meeting concrete needs, yaitu mempertemukan kebutuhan siswa secara jelas. Kedua, pada tahap responding disebut sebagai dealing with specific experience, yaitu proses mengarahkan suatu pengalaman siswa. Ketiga, tahap personalizing disebut sebagai concretizing problems, yaitu proses memperjelas masalah. Keempat, pada tahap initiating disebut sebagai being fully specific, yaitu proses spesifikasi masalah. Kelima, pada tahap helping disebut sebagai being pragmatic, yaitu membuat praktis suatu solusi yang diambil siswa.

Kekonkretan dan kekhususan ekspresi lebih mengarah kepada komunikasi verbal. Kondisi ini mengisyaratkan adanya kejelasan ungkapan guru bimbingan dan konseling sehingga mudah dipahami siswa. Guru bimbingan dan konseling memusatkan pembicaraan pada perasaan, pemikiran, dan pengalaman siswa. Selain itu, guru BK perlu berupaya untuk berkomunikasi secara teliti dan jelas serta mau memperjelas pernyataan siswa.

Dengan kekonkretan komunikasi, siswa akan terhindar dari kecemasan, kebingungan,dan kekesalan. Kejelasan komunikasi antara guru BK dengan siswa merupakan aspek yang esensial bagi efektivitas pemberian bantuan. Blander dan Grinder menyatakan ...indicate how helping clarifies konseli sentences, give konselis better wayto describe themselves, and provides them with sharper descriptive thoughts abouttheir problems (Brammer, 2003, p. 78). 


\section{SIMPULAN}

Dalam pemberian layanannya, guru bimbingan dan konseling perlu menciptakan situasi yang menimbulkan pengaruh dengan memiliki keterampilan-keterampilan untuk mengembangkan komunikasi bimbingan dan konseling. Keterampilan tersebut meliputi: (1) keterampilan untuk memahami siswa dan memberikan pemahaman kepadanya agar ia menyadari akan masalahnya dan mampu mengembangkan potensi diri (helping skills for understanding), (2) keterampilan untuk mengarahkan siswa kepada suatu proses pembuatan pilihan (helping skills for comfort), dan (3) keterampilan untuk memfasilitasi siswa agar mampu mengambil keputusan dan siap untuk melaksanakannya (helping skills for action).

Kompetensi komunikasi yang harus dimiliki guru bimbingan dan konseling agar siswa mau meminta dan menerima bantuan guru BK adalah kemampuan untuk menumbuhkan kepercayaan siswa kepada guru BK, kemampuan untuk menghargai siswa, dan kemampuan memberi kebebasan kepada siswa dalam mengekspresikan permasalahannya.

Kompetensi yang seyogianya dikuasai guru bimbingan dan konseling agar tercipta komunikasi yang menumbuhkan, meliputi: (1) keterampilan berempati, (2) keterampilan memberikan penghargaan terhadap pribadi siswa, (3) keterampilan untuk menciptakan interaksi guru BK dan siswa dengan nuansa emosional psikologis yang hangat dan penuh perhatian, (4) keterampilan untuk mengungkapkan pembicaraan secara tulus dan terbuka, dan (5) keterampilan mengemukakan pembicaraan secara konkret disertai kesesuaian ekspresi.

\section{REFERENSI}

Blocher, D. H. (2006). Developmental counseling. New York: John Willey \& Son.

Brammer, L. M. (2003). The helping relationship process and skils (SecondEdition). Englewood Cliffs, New Jersey: Prentice-Hall.

Carkhuff, R. R. (2000). The art of helping in the 21st century (Vol. 8). Pelham, MA: Human Resource Development Press.

Egan, G. (2002). The skilled helper: models, skills, and methodes for effective helping. Monterey, California: Brooke Cole Publishing.

Muro, J. J., \& Kottman, T. (2005). Guidance and counseling in the elementary and midde schools. Agoura, CA: Brown \& Benchmark.

Myrick, R. D. (2003). Developmental guidance and counseing: A practical approach (second Edition), Minneapolis: Educational Media Coorporation.

Nugent, F. A. (2001). Professional counseling. Belmont, California: Brooks Cole Publishing Company. 
INDONESIAN JOURNAL OF EDUCATIONAL COUNSELING 2019, 3(3), 169-178

Osipow, S. H., Walsh, W. B., \& Tosi, D. J. (1984). A survey of counseling methods. Illinois: Dorsey Press.

Shaw, M. E., \& Coustanzo. (1982). Theories of social psychology. Singapore: McGraw-Hill Book Company.

Schmidt, J. J. (2004). Counseling in school essential service and comprehensive programs. Boston: Aliyah Bacon.

Shetzer, B., \& Stone, S. (2000). Fundamental of counseling. Boston: Houghton Mifflin Company.

Yusuf, S. L. N. (2010). Psikologi perkembangan anak dan remaja. Bandung: Remaja Rosdakarya. 